\title{
EFEKTIVITAS MODEL PEMBELAJARAN KOOPERATIF TIPE GROUP INVESTIGATION (GI) BERBANTUAN LKS (LEMBAR KERJA SISWA) PADA MATERI KALOR UNTUK MENINGKATKAN PEMAHAMAN KONSEP SISWA SD KELAS V
}

\author{
N.W. S. Darmayanti ${ }^{1}$, Dsk. Pt. Anom Jana Wati ${ }^{1}$, I. Nym. Sudirman ${ }^{1)}$, \\ I.K.Wisnu Budi Wijaya'), Linda Sekar Utami3) \\ 1)Program Studi Pendidikan Guru Sekolah Dasar, STKIP Suar Bangli, Bali, Indonesia \\ 2)Program Studi Pendidikan Guru Sekolah Dasar, IHDN Denpasar, Bali, Indonesia \\ ${ }^{3)}$ Program Studi Pendidikan Fisika, FKIP, Universitas Muhammadiyah Mataram, Mataram, NTB, Indonesia \\ ${ }^{*}$ Corresponding author: N.W. S. Darmayanti \\ E-mail : wyndarmayanti@gmail.com
}

Diterima 27 April 2020, Disetujui 6 Mei 2020

\begin{abstract}
ABSTRAK
Penelitian ini bertujuan untuk mengetahui efektivitas model pembelajaran kooperatif tipe GI berbantuan LKS pada materi kalor untuk meningkatkan pemahaman konsep siswa SD kelas V. Jenis penelitian ini adalah Pre-Eksperimen. Desain yang digunakan adalah One-Group Pretest-Posttest Design dimana terdapat Pretest sebelum perlakuan dan posttest setelah perlakuan. Pada penelitian ini menggunakan seluruh siswa kelas V SD Negeri 1 Tampaksiring sebagai sampel penelitian. Data pemahaman konsep dikumpulkan dengan tes pemahaman konsep berbentuk tes essay. Data dianalisis menggunakan Gain Score. Hasil penelitian menunjukkan bahwa model pembelajaran kooperatif tipe GI berbantuan LKS pada materi kalor efektif meningkatkan pemahaman konsep siswa dengan gain score 0,40 yang berada pada kategori sedang (berada pada rentangan $0,7 \geq g \geq 0,3$ ).
\end{abstract}

Kata Kunci: model kooperatif tipe Gl; pemahaman konsep.

\begin{abstract}
This research aims to determine the effectiveness of the GI type worksheets -assisted cooperative learning model on heat material to improve the concept understanding of elementary school students in grade V. The type of this research is Pre-Experimen. The design used is the One-Group Pretest-Posttest Design where there are pretest before treatment and posttest after treatment. In this research using all fifth grade students of SD Negeri 1 Tampaksiring as research samples. Concept understanding data was collected with a concept understanding test in the form of an essay test. Data were analyzed using Gain Score. The results showed that the cooperative learning model of GI type assisted by worksheets on heat material was effective in improving students' understanding of concepts with a gain score of 0.40 in the medium category (in the range of $0.7 \geq g \geq 0.3$ ).
\end{abstract}

Keywords: GI type cooperative model; concept understanding.

\section{PENDAHULUAN}

Guru merupakan ujung tombak pendidikan yang harus mampu merencanakan, melaksanakan, dan mengevaluasi pembelajaran. Untuk itu guru harus selalu mengembangkan diri untuk mencapai kompetensi profesionalisme salah satunya guru dapat memilih model-model pembelajaran yang inovatif sehingga dapat menciptakan proses pembelajaran yang optimal. Proses pembelajaran yang baik tentunya akan berpengaruh pada pemahaman siswa terhadap materi yang disampaikan guru. Sasaran utama dari kegiatan pembelajaran terletak pada proses belajar peserta didik, yang harus mengutamakan belajar siswa secara aktif, karena sasaran pendidikan adalah proses pembelajaran siswa, bukan semata-mata mengukur hasil belajar siswa. Namun kenyataannya, masih banyak masalahmasalah yang ditemukan pada proses pembelajaran. Berdasarkan dari hasil observasi yang dilakukan peneliti di kelas $V$ SD Negeri 1 Tampaksiring, bahwa dalam proses pembelajaran khususnya pelajaran IPA materi kalor masih terdapat siswa yang nilainya berada di bawah kriteria ketuntasan Minimal (KKM). Sebagian siswa menganggap sulit dan kurang paham pada materi pelajaran tersebut. Nilai rata-rata ulangan harian siswa pada materi kalor adalah sebesar 76 dengan KKM IPA 
sebesar 72. Meskipun nilai rata-rata pembelajaran IPA sudah di atas KKM, namun masih ada siswa yang mendapatkan nilai dibawah KKM. Hal tersebut dikarenakan pada proses pembelajaran metode yang digunakan kurang variatif serta belum menggunakan media yang cocok sehingga membuat siswa kurang bersemangat dan bosan dalam mengikuti pelajaran. Semua hal tersebut memberikan dampak pada rendahnya pemahaman konsep siswa.

$$
\text { Paparan situasi tersebut }
$$

mengindikasikan perlu diterapkan model pembelajaran inovatif yang mampu menciptakan proses pembelajaran efektif dan optimal, sehingga dapat mengoptimalkan pemahaman konsep siswa. Kegiatan pembelajaran disusun sedemikian rupa sehingga memberikan kesempatan bagi siswa untuk berdiskusi, terkait ide-ide ataupun konsep-konsep sehingga konsep tersebut benar-benar mampu dipahami oleh siswa. Efektivitas kegiatan pembelajaran dapat dioptimalkan ketika siswa diorganisasikan dalam suatu kelompok kecil, sehingga mampu saling tanggung jawab, dan belajar untuk menghargai satu sama lain, tanpa memandang perbedaan suku, atau perbedaan-perbedaan lain yang berpengaruh terhadap kegiatan belajar. Model pembelajaran yang mampu menjawab tantangan tersebut adalah model pembelajaran kooperatif.

Pembelajaran kooperatif menurut Trianto (2007) merupakan model pembelajaran yang melibatkan siswa di mana siswa berkolaborasi untuk mencapai tujuan bersama. Pada pembelajaran kooperatif, siswa didorong untuk memecahkan masalah belajar melalui interaksi sosial. Pemecahan masalah belajar dapat dilakukan melalui kelompok-kelompok kecil. Model pembelajaran kooperatif yang memberikan kesempatan bagi siswa secara optimal untuk belajar mandiri memaknai materi serta mengolaborasinya secara lebih mendalam dalam kegiatan diskusi adalah model pembelajaran kooperatif tipe GI. Nurhadi, dkk (dalam Wena, 2009) menyatakan bahwa GI adalah salah satu bentuk pembelajaran kooperatif di mana siswa aktif berpartisipasi dalam mencari materi yang dibahas untuk memecahkan permasalahan yang diberikan sehingga siswa lebih paham terhadap konsep.

Slavin (1995) menyatakan kegiatan pembelajaran GI memiliki enam langkah pembelajaran, yaitu (1) grouping (menentukan jumlah anggota dalam kelompok, sumber, topik, serta merumuskan permasalahan), (2) planning (menetapkan yang dipelajari, bagaimana mempelajari, apa tujuannya), (3) investigation (berdiskusi dan tukar informasi, klarifikasi, menganalisis data, membuat inferensi), (4) organizing (anggota kelompok menulis laporan, merencanakan presentasi laporan), (5) presenting (salah satu kelompok menyajikan, kelompok lain berperan secara aktif sebagai pendengar (audiens), (6) evaluating (melakukan koreksi laporan sesuai hasil diskusi kelas, siswa dan guru berkolaborasi mengevaluasi pembelajaran yang telah dilaksanakan dan melakukan penilaian kompetensi pencapaian pemahaman). Model pembelajaran ini menjadi lebih lengkap dipadukan dengan media lembar kerja atau LKS (Lembar Kerja Siswa). Guru memberikan Lembar kerja pada saat akan melakukan diskusi sebagai bahan yang akan didiskusikan. Bagi pendidik, lembar kerja dapat memberi kesempatan kepada pendidik untuk memancing siswa aktif terlibat dengan materi yang dibahas (Prastowo, 2014).

Sesuai dengan hasil penelitian dari Aliwu, dkk (2016) bahwa penerapan model pembelajaran kooperatif tipe GI dapat meningkatkan aktivitas dan hasil belajar siswa SD kelas VI. Suasana belajar terasa lebih efektif serta melalui kerjasama kelompok siswa memiliki semangat dan keberanian dalam berpendapat dan bertukar informasi terkait materi yang dibahas. Selain itu hasil penelitian dari Artini, dkk (2016) juga menunjukkan bahwa model pembelajaran $\mathrm{Gl}$ dapat meningkatkan aktivitas guru dan siswa SD Kelas VI. Model pembelajaran kooperatif tipe GI yang berbantuan LKS ini akan membantu siswa lebih aktif dan paham dengan konsep-konsep IPA khususnya materi kalor.

Berdasarkan uraian di atas, penulis tertarik untuk meneliti terkait model pembelajaran kooperatif tipe GI berbantuan LKS untuk mengetahui efektivitas model pembelajaran kooperatif tipe Gl berbantuan LKS pada materi kalor untuk meningkatkan pemahaman konsep siswa SD kelas V. Atas dasar tersebut peneliti mengambil judul penelitian" Efektivitas Model Pembelajaran Kooperatif Tipe Group Investigation (GI) Berbantuan LKS Pada Materi Kalor untuk Meningkatkan Pemahaman Konsep Siswa SD Kelas V".

\section{METODE PENELITIAN}

Rancangan penelitian ini menggunakan rancangan penelitian kuantitatif, di mana untuk menguji hipotesis yang ditetapkan memerlukan pengumpulan data menggunakan instrumen penelitian serta analisis data bersifat kuantitatif (Sugiyono, 2013). Jenis penelitian ini adalah Pre-Eksperimen karena tidak adanya variabel kontrol dan sampel tidak dipilih secara random 
sehingga masih terdapat variabel luar yang berpengaruh terhadap terbentuknya variabel dependen (Sugiyono 2013). Desain yang digunakan adalah One-Group Pretest-Posttest Design dimana terdapat Pretest sebelum perlakuan dan posttest setelah perlakuan.

\section{Teknik Pengumpulan Data}

Teknik pengumpulan data dalam penelitian eksperimen ini dilakukan melalui tahapan-tahapan sebagai berikut: 1. Tahapan persiapan, langkah pertama yang dilakukan adalah menyusun RPP, tes pemahaman konsep sesuai dengan materi dan silabus. Selanjutnya melakukan uji coba instrumen pemahaman konsep kemudian dilanjutkan analisis instrument tersebut. 2. Tahap eksperimen, siswa terlebih dahulu diberikan pre-test dengan menggunakan tes pemahaman konsep selanjutnya siswa diajarkan materi sesuai dengan RPP dan menggunakan model yang sudah ditentukan. 3 Tahap akhir, setelah tahapan eksperimen dilakukan kemudian dengan tahap (post-test) dengan tes pemahaman konsep.

\section{Tehnik Analisa Data}

\section{Pemahaman}

konsep diukur menggunakan tes pemahaman konsep berupa tes essay. Skor tertinggi adalah 10 setiap soal. Untuk mengetahui besarnya peningkatan pemahaman konsep kalor siswa digunakan uji gain score. Analisis data siswa digunakan uji gain dengan persamaan :

$$
\text { gain }=\frac{S_{\text {post }}-S_{\text {pre }}}{S_{\text {maks }}-S_{\text {pre }}}
$$

Keterangan:

$$
g \text { (gain) = gain }
$$

$S_{\text {pre }}=$ skor awal

$S_{\text {post }}=$ skor akhir

$\boldsymbol{S}_{\text {maks }}=$ skor maksimum

Data hasil perhitungan skor pemahaman konsep siswa sebelum dan sesudah penerapan model pembelajaran kooperatif tipe GI berbantuan LKS kemudian akan diiterpretasikan dengan menggunakan gain standar. Di mana nilai gain $>0,7$ tergolong peningkatan tinggi, nilai gain $0,7 \geq g \geq 0,3$ tergolong peningkatan sedang, dan nilai gain < 0,3 tergolong peningkatan rendah. Apabila model pembelajaran kooperatif tipe GI berbantuan LKS dapat meningkatkan pemahaman konsep siswa, maka dikatakan telah teruji keefektifannya.

\section{HASIL DAN PEMBAHASAN \\ Hasil \\ Hasil Uji Coba \\ Uji Validitas Instrumen}

Instrumen pemahaman konsep

berupa tes essay yang berjumlah 10 soal. Sebelum instrumen tersebut digunakan terlebih dahulu diujikan tingkat validitas atau kesahihannya untuk digunakan sebagai instrumen penelitian yang layak untuk pemahaman konsep. Uji coba instrumen dilakukan pada siswa kelas VI dengan jumlah siswa sebanyak 33 orang yang telah mendapatkan materi kalor. Uji validitas menggunakan korelasi Product Momen. Hasil uji validitas dengan jumlah responden $(N)=33$ dan taraf signifikansi $5 \%$ dengan $r$ tabel $=0,349$, dikatakan valid jika $r_{x y}>r$ tabel maka diperoleh 6 soal valid dan 4 soal tidak valid.

\section{Uji Reliabilitas Instrumen}

Uji coba reliabilitas instrumen bertujuan untuk menentukan butir soal yang mempunyai taraf kepercayaan yang tinggi.Uji coba reliabilitas menggunakan rumus Alfa Cronbach, jika $r$ hitung lebih besar dari $r$ tabel $(0,349)$ dengan taraf signifikan 5\% maka instrumen tersebut

reliabel. Soal berjumlah 10 butir soal dengan responden 33 orang. Hasil dari uji reliabelitas diperoleh $r(r$ hitung) lebih besar dari $r$ tabel 0,55> 0,349 maka instrumen tes pemahaman konsep yang berjumlah 10 soal dapat dinyatakan reliabel.

\section{Uji Tingkat Kesukaran Butir Soal}

Tingkat kesukaran soal ditentukan berdasarkan banyak siswa yang menjawab soal dengan benar dibagi jumlah seluruh siswa peserta tes. Kriteria soal yang baik adalah soal yang tidak terlalu mudah atau tidak terlalu sukar. Berdasarkan hasil uji tingkat kesukaran soal, maka terdapat 6 buah soal yang berkategori sedang, 2 buah soal berkategori sukar, dan 2 buah soal berkategori mudah.

\section{Uji Daya Beda Soal}

Daya pembeda butir soal bertujuan untuk mengukur sejauh mana butir soal tertentu mampu membedakan antara anak yang pandai dengan anak yang kurang pandai berdasarkan kriteria tertentu. Berdasarkan hasil uji coba daya beda soal, maka terdapat 6 soal berkategori cukup, 2 butir soal berkategori baik, dan 2 soal berkategori jelek.

Soal yang dipakai dalam penelitian ini adalah berjumlah 5 butir soal dengan skor maksimalnya 50 point dan skor minimalnya adalah 10 point. 


\section{Deskripsi Data Pemahaman Konsep untuk Pre-test dan Post-test}

Data skor pemahaman konsep diporoleh dengan menjawab tes pemahaman konsep yang dikerjakan sebelum diberikan materi kalor dan setelah penyampaian materi kalor selesai. Adapun deskripsi skor dari pemahaman konsep untuk pre-test dan posttest, terdapat pada Tabel 1 dan 2 berikut.

Tabel.1 Deskripsi skor pemahaman konsep untuk pre-test

\begin{tabular}{lc}
\hline & Skor \\
\hline Rata-rata & 32.69 \\
\hline Median & 33.0 \\
\hline Modus & 36.0 \\
\hline Jangkauan & 13.0 \\
\hline Skor Maksimum & 40.0 \\
\hline Skor Minimum & 27.0 \\
\hline Standar Deviasi & 3.4 \\
\hline Varians & 11.3 \\
\hline
\end{tabular}

Tabel. 2 Deskripsi skor pemahaman konsep untuk post-test

\begin{tabular}{lc}
\hline & Skor \\
\hline Rata-rata & 43.54 \\
\hline Median & 44.0 \\
\hline Modus & 42.0 \\
\hline Jangkauan & 7.0 \\
\hline Skor Maksimum & 47.0 \\
\hline Skor Minimum & 40.0 \\
\hline Standar Deviasi & 1.8 \\
\hline Varians & 3.3 \\
\hline
\end{tabular}

Berdasarkan tabel 1 dan 2, rata-rata skor pemahaman konsep untuk post-test lebih besar daripada skor pre-test.

\section{Hasil Uji Gain Score}

Data skor pemahaman konsep siswa diuji menggunakan gain score untuk mengetahui apakah ada peningkatan pemahaman konsep kalor antara sebelum dan sesudah diberikan perlakuan. Adapun data hasil uji gain score terdapat pada Tabel 3 berikut.

Tabel. 3 Hasil uji gain score untuk pemahaman konsep

\begin{tabular}{llcl}
\hline & Pre-test & $\begin{array}{c}\text { Post- } \\
\text { test }\end{array}$ & $\begin{array}{c}\text { Gain } \\
\text { Score }\end{array}$ \\
\hline Rata-rata & 32.69 & 43.54 & 0.40 \\
\hline Median & & & 0.40 \\
\hline Modus & & & 0.40 \\
\hline
\end{tabular}

\begin{tabular}{ll}
\hline Jangkauan & 0.14 \\
\hline Skor gain maksimum & 0.45 \\
\hline Skor gain minimum & 0.32 \\
\hline Standar deviasi & 0.03 \\
\hline Varians & 0.00 \\
\hline
\end{tabular}

Adapun grafik gain score pemahaman konsep siswa dapat dilihat pada Gambar 1 berikut.

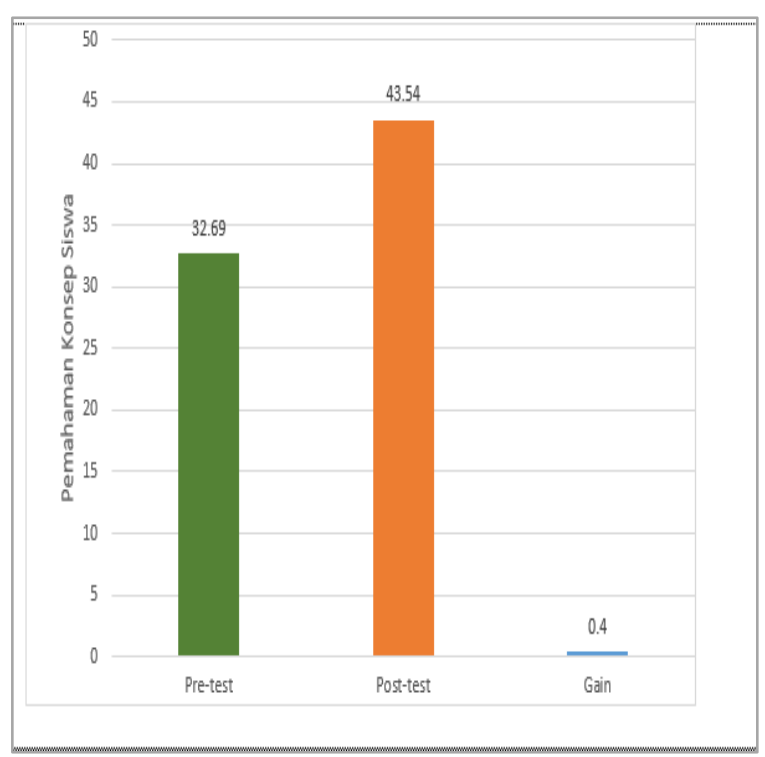

Gambar 1. Grafik gain score pemahaman konsep siswa

Sesuai dengan tabel 3 dan gambar 1 , yang menunjukkan bahwa rata-rata gain score untuk pemahaman konsep siswa adalah 0,40 berada pada rentangan $0,7 \geq g \geq 0,3$ yang berkategori sedang.

\section{Pembahasan}

Berdasarkan hasil analisis data penelitian, adapun pembahasan tentang hasil penelitian adalah sebagai berikut. Skor ratarata pemahaman konsep siswa untuk pre-test adalah sebesar 32, 69 dan skor rata-rata pemahaman konsep siswa untuk post-test adalah sebesar 43,54. Skor rata-rata pemahaman konsep siswa untuk post-test lebih besar dibandingkan pre-test. Selain itu, jika dikonversi dalam bentuk nilai, maka nilai ratarata pada post-test lebih besar dibandingkan pre-test. Nilai pemahaman konsep siswa pada post-test semuanya di atas KKM sekolah. Siswa-siswa lebih banyak menjawab benar pada tes pemahaman konsep yang diberikan pada saat post-test. Hal ini menunjukkan bahwa model pembelajaran kooperatif tipe GI berbantuan LKS pada materi kalor efektif diterapkan karena skor dan nilai rata-rata pemahaman konsep siswa menjadi meningkat. 
Rata-rata gain score untuk pemahaman konsep siswa adalah 0,40 berada pada rentangan $0,7 \geq g \geq 0,3$ yang berkategori sedang. Hal ini menunjukkan bahwa telah terjadi peningkatan pemahaman konsep siswa dengan kategori sedang. Hal tersebut menyatakan bahwa model pembelajaran yang diterapkan, yaitu model pembelajaran kooperatif tipe GI berbantuan LKS pada materi kalor efektif dapat meningkatkan pemahaman konsep siswa dalam kategori sedang. Model pembelajaran kooperatif tipe GI memiliki dasar filosofis dari Vygotski dan Piaget, di mana Vygotsky (dalam Slavin, 1995) menyatakan bahwa proses belajar terjadi secara efisien dan efektif jika anak belajar bekerjasama dengan anak lainnya dalam satu kelompok didukung oleh lingkungan yang bagus serta di bawah bimbingan guru.

Model kooperatif tipe $\mathrm{Gl}$ mempunyai kelebihan Menurut Setiawan (dalam Irawan \& Ningrum, 2016) salah satunya adalah pada proses belajarnya dapat bekerja secara bebas untuk berkolaborasi dan berdiskusi dengan teman, memberi semangat untuk berinisiatif, kreatif, dan aktif; rasa percaya diri dapat lebih meningkat; dapat belajar untuk memecahkan, menangani suatu masalah. Siswa terlibat langsung dalam mencari materi dan memecahkan permasalahan yang diberikan pada LKS maka siswa menjadi lebih paham terhadap materi yang dibahas karena siswa tersebut menemukan sendiri cara untuk memecahkan permasalahan tersebut.

Penerapan model pembelajaran kooperattif tipe GI juga dibantu dengan LKS, di mana jika dilihat dari fungsi LKS menurut (Prastowo, 2014) adalah sebagai bahan ajar yang bisa meminimalkan peran pendidik, namun lebih mengaktifkan peserta didik serta mempermudah peserta didik untuk memahami materi yang diberikan. Dengan adanya bantuan LKS siswa lebih aktif mencari materi dan referensi untuk memecahkan permasalahan yang tersedia dalam LKS tersebut sehigga siswa menjadi lebih paham terhadap materi. Pada penelitian ini kategori peningkatan pemahaman konsep siswa belum bisa optimal (berkategori tinggi), karena peningkatan skor masing-masing siswa masih dalam kategori sedang. Selain itu untuk mendapatkan hasil peningkatan yang optimal diperlukan waktu yang cukup dan penerapan model secara berkelanjutan. Meskipun kategori peningkatan pemahaman konsep kalor pada kategori sedang, namun nilai semua siswa berada di atas KKM sekolah.

\section{SIMPULAN DAN SARAN Simpulan}

Berdasarkan hasil penelitian dan pembahasan diuraikan simpulan sebagai berikut.

Model pembelajaran kooperatif tipe GI berbantuan LKS pada materi kalor efektif meningkatkan pemahaman konsep siswa dengan gain score 0,40 yang berada pada kategori sedang (berada pada rentangan $0,7 \geq$ $g \geq 0,3$ ).

\section{Saran}

Berdasarkan hasil penelitian yang telah dilakukan, penulis mengajukan saran sebagai berikut.

Pengajar hendaknya dapat memilih media, metode dan model pembelajaran inovatif yang dapat meningkatkan pemahaman konsep siswa. Selain itu, perlu penelitian lebih lanjut dengan penerapan model pembelajaran kooperatif tipe GI berbantuan LKS pada mata pelajaran ataupun kelas yang berbeda.

\section{DAFTAR RUJUKAN}

Aliwu, Y., Hatibe, A., \& Rede, A. (2016). Penerapan model pembelajaran kooperatif tipe group investigasi untuk meningkatkan aktivitas dan hasil belajar siswa kelas VI SDN No 1 Labuan Bajo. E-Jurnal Mitra Sains.4 (2). Hal 46-53.

Artini., Pasaribu, M., \& Husain, S. (2016). Penerapan model pembelajaran kooperatif tipe group investigation untuk meningkatkan aktivitas dan hasil belajar ipa pada siswa kelas VI SD Inpres 1 Tondo. e-Jurnal Mitra Sains. 4 (1). Hal 76-83.

Irawan, F. J, \& Ningrum. (2016). Pengaruh Penggunaan Model Cooperative Learning Tipe Group Investigation (Gi) Terhadap Hasil Belajar Prakarya Dan Kewirausahaan (Pkwu) Siswa Kelas X Semester Genap Smk Negeri 1 Metro TP 2015-2016. JURNAL PROMOSI. 4 (2). Hal 61-68.

Prastowo, A. (2014). Panduan Kreatif Membuat Bahan Ajar Inovatif. Yogyakarta Diva Press.

Slavin, R. E. (1995). Cooperative learning. Second edition. Boston: Allyn and Bacon.

Sugiyono. (2013). Metode penelitian pendidikan (pendekatan kuantitatif, kualitatif dan R\&D). Bandung: Alfabeta.

Trianto. (2007). Model-model pembelajaran inovatif berorientasi kontruktivistik: Konsep, landasan teoritis-praktis dan 
implementasinya. Jakarta: Prestasi Pustaka.

Wena, M. (2011). Strategi Pembelajaran Inovatif Kontemporer. Jakarta: Bumi Aksara. 